\title{
PSYCHOANALYSIS AND PSYCHOSIS: PLAYERS AND HISTORY IN THE UNITED STATES
}

\author{
Ann-Louise S. Silver, Columbia, MD
}

\section{Introduction}

This paper challenges five assumptions: (1) that US interest in analysis began with Freud's Clark Lectures; (2) that Americans prior to the early 1930s had a practical, naively optimistic, non-theoretical interest in psychoanalysis; (3) that serious psychoanalytic work with severe mental illness began only after World War II; (4) that such work used classical analytic techniques; and, finally, (5) that psychoanalytically-oriented work with the severely ill has been deemed outmoded or even dangerous and has ceased in the United States.

Freud aptly called us the 'practical Americans'. Home of William James's pragmatism and C.S. Peirce's pragmaticism, American psychiatry has long attempted a can-do attitude towards treating mental illness, as promulgated by James's and Peirce's contemporary, Swiss-born and -educated, Adolf Meyer. ' 'Starting in 1906, Meyer urged members of his staff to acquire a knowledge of psychoanalytic theory and practice' (Leys 1981). In a 1908 unpublished report, Meyer said, 'In the large and prognostically gloomy field

ANN-LOUISE SILVER MD was on the Chestnut Lodge staff for 25 years until its closure in April 2001. She is an Adjunct Professor of Psychiatry at the Uniformed Services University of the Health Sciences and a Civilian Consultant to the Military Residency Program. She is on the faculties of the Washington Psychoanalytic Institute and the Washington School of Psychiatry. She is a past President of the American Academy of Psychoanalysis and is on the executive board of the International Society for the Psychological treatments of Schizophrenia and other psychoses (ISPS) and is president of its United States Chapter. She edited Psychoanalysis and Psychosis, published in 1989 by International Universities Press. Address for correspondence: 4966 Reedy Brook Lane, Columbia, MD 21044-1514, USA. [email: asilver@ psychoanalysis.net]

1. Letter from August Hoch to Adolf Meyer, 29 December 1904. 'I have been thinking a good deal about dementia praecox, and have come to the conclusion that we might call the disease or whatever name we may give to it a process of dissociation for which we have analogies in dream, delirium, and hysteria' (Grob 1985, p. 22). Meyer's response, 30 December, advocated the role of habit-disorder over dissociation. 'I amused myself yesterday with a tabulation of about one-half of my dementia praecox cases to see about the onset of the first plain symptoms, and the time of admission; it is really remarkable how many cases had long premonitory stages, and it will be our duty to single out the cases of supposedly acute onset; their number grows smaller as one looks up the facts more carefully, and where the trouble seems to have arisen suddenly, the frequency of the difficulty of coping with some actual situation, such as sexual interests, is very striking.' (Grob, p. 24) 
of dementia praecox, as well as in number [sic] of other functional types, we feel that it is our duty to attempt a psychoanalysis in every accessible case. This, of course, takes much time and painstaking work' (M. Engel 1990, p. 171). The following year, he wrote, citing John Gray, Superintendent at the Utica State Hospital. ${ }^{2}$ Gray had written in 1871 that the mind cannot become diseased; only the brain can, a notion rather pervasively held (Meyer 1909, p. 325). This led to dead-end diagnosis and warehousing. Even by the time of the Clark Lectures in 1909, waves of immigration had doubled state hospital populations, and professionals felt increasingly overwhelmed. Psychological approaches offered a new possibility of cure.

When Freud arrived at Clark University, in September 1909, he, Jung, Meyer and the other 25 speakers each received honorary degrees. We tend to forget this third analyst honored at Clark who was among the eight founders of the American Psychoanalytic Association in May 1911 in Baltimore. Meyer was the key figure to lay the groundwork for the enthusiastic reception of Frieda Fromm-Reichmann decades later when she arrived in the US in 1935. Meyer had taught nationally the importance of charting patients' life stories. He effectively advocated having the schizophrenias presented in the American Psychiatric Association's Diagnostic and Statistical Manual as schizophrenic reactions, that is, secondary to inner conflict rather than to neurologic deficit.

Having emigrated from Switzerland in 1892 at the age of 26, Meyer traveled home frequently, maintaining his ties with the Burgholzli, where he trained. His teacher, August Forel, would later successfully treat Meyer's mother's depression there. Meyer, at first in Illinois, worked closely with John Dewey and George Herbert Mead in the social applications of pragmatism. They formed the Chicago School of the Social Sciences, which would later inspire Harry Stack Sullivan. At the time of the Clark Lectures, Meyer was the Director of the Pathological Institute of the State Hospitals, located in New York City, and headed the editorial board of the Bulletin of the New York State Hospitals. His lecture at Clark University was entitled 'The dynamic interpretation of dementia praecox'. ${ }^{3}$

He would later become the first head of the department of psychiatry at the Johns Hopkins Hospital's Henry Phipps Clinic, which opened in April 1913, with Ernest Jones among the speakers Meyer invited. There, Meyer in

2. For a long time it was New York State's only mental hospital, at first called The New York State Lunatic Asylum.

3. 'We owe to our European guests, Professor Freud and Dr Jung, the demonstration that what is at work in the centre of the stage is a complex or group of complexes consisting of insufficiently balanced experiences in various ways modified by symbolism. Their ingenious interpretations have made possible a remarkable clearing up of many otherwise perplexing products of morbid fancy, in ways the discussion of which, no doubt, I had better leave to their lectures.' (Meyer 1910, p. 389)
1924 treated Horace Frink, Freud's American emissary when Frink became psychotically depressed. Meyer was displeased with what he felt was Freud's abandonment of his patient, and Meyer left the analytic movement (Edmunds 1988). However, his ambivalence towards psychoanalysis was evident in 1910, in his reaction to a paper by Jones, especially as it resonated with a particular sexual scandal and its ramifications at Hopkins (Leys 1981).

People generally think of Washington, DC, New York City, and Topeka, $\mathrm{KS}$, as the US originating centers for the psychoanalytic treatment of psychosis. Those from the United States would include Boston ${ }^{4}$ and its McLean Hospital; New Haven, home of Yale University; Stockbridge, Massachusetts s Austen Riggs Center; San Francisco, home of the Boyer House; and Chicago. But the very beginnings of interest in psychodynamic applications to severe mental illness were in upstate New York - at the state hospitals in Binghamton and Utica, and in New York City and Worcester, Massachusetts.

This paper emphasizes the earliest years in the United States of interest in applying psychoanalytic concepts to the treatment of schizophrenia. This history is less known than the post-World War II literature. Harry Stack Sullivan's most quoted aphorism, 'We are all more simply human than otherwise' has its origins in the works of James Jackson Putnam, ${ }^{5}$ C. Macfie Campbell, ${ }^{6}$ William Alanson White, ${ }^{7}$ in the first decade of the twentieth

4. In 1917, Coriat reported on the successful treatment of five schizophrenic patients. This contrasts sharply with his 1914 book, Abnormal Psychology, where he says dementia praecox cannot be treated by psychoanalytic methods. 'By means of [the association method] we are able to prove that many insane ideas, delusions, hallucinations, and dreams take their origin in previous experiences, which were preserved in the unconscious as dormant complexes or memories. Investigations along these lines by certain German investigators (Jung, Freud, Bleuler, and the Zurich school) have thrown an immense amount of light upon hysteria and upon the psychogenesis of dementia praecox' (Coriat 1914, p. 91). 'But why one form of mental dissociation should cause a curable hysteria and the other an incurable dementia praecox cannot be definitely answered at present' (Coriat 1914, p. 94).

5. 'A caricature, a monstrosity is not, it is true, simply a magnified image of the normal, and cannot be taken as giving more than a hint of what will there be found. But then, it is not to be forgotten that the true 'normal' exists only in name.' (Hale 1971b, p. 121, from Putnam, review of The Dissociation of a Personality, J. Abnormal Psychology, 1 (October 1906), p. 238. Both the book and the journal editor, Morton Prince.)

6. '... patients in their delusions merely use mechanisms which are already well known to us, and ... it is not so much the creation of these imaginative products, which separates them from their sane fellow men, but rather the setting of life and conduct in which these products occur. The same mechanisms are seen, wherever play is given to the imagination, whether in artistic creation or in dreams or in psychopathology.' (Campbell 1909, p. 17)

7. 'The difference between the so-called insane person or the criminal on the one hand and the so-called sane or normal person on the other is only a difference in quantity, a difference in the strength or weakness and the balanced relations of the various tendencies and stimuli with which he has to deal.' (White 1933, p. 31) 
century. Their egalitarianism grew naturally from the Declaration of Independence: 'All men are created equal .. .'. Freud had little interest in working with psychotic patients and was not fond of the United States. But he was astounded to find so many American clinicians and teachers coming to hear him and Jung speak at Clark University. Sandor Ferenczi, who accompanied them, would have his own profound influence later, through his writings and his visit to the US in 1926 . He promoted an active analytic stance, a necessity in work with psychotic patients (Silver 1993).

The Americans listened attentively to Freud's lectures, which he delivered in German. Freud was kept going financially during the enormously difficult years of World War I and afterwards by the many Americans who came to Vienna for their personal analyses, most of whom worked with psychotic as well as neurotic patients. The Clark University conference organizer, Granville Stanley Hall, $\mathrm{PhD}^{8}$ is usually credited with launching American interest in psychoanalysis by organizing the Clark Lectures, but this is not quite so. The ball was already rolling. An interesting historical footnote: coincidental with the Clark Lectures, and also by invitation, Bertha Pappenheim, Anna O., was on her own lecture tour in Canada, Chicago and New York. ${ }^{9}$

As I reviewed the earliest volumes of the Bulletin of the New York State Hospitals, which began in 1908, I found its lead article written by Adolf Meyer. He had, prior to this, written and spoken on the topic of psychogenic disorders. ${ }^{10}$ As I read further in the minutes of the reports from the

8. Hall was Clark University's first president, then went on to Johns Hopkins University where he established the country's contestedly first experimental psychology laboratory. He had founded and edited the American Journal of Psychology beginning in 1887, the first such journal in English (Rosenzweig 1992, p. 92).

9. 'Like Stanley Hall, whom she never met, Pappenheim attributed neurotic adjustments and social evils involving sexuality primarily not to unconscious conflicts but to quite conscious ones between classes of citizens who tolerate poverty, inferior education and economic exploitation' (Rosenzweig 1992, p. 109). I enthusiastically recommend her biography by M. Guttmann (2001).

10. Meyer's opening sentence remains current: 'There prevails a widely spread idea that it is no easy matter to interest physicians and medical students in mental disease. In the first place medical training is usually directly opposed in its whole tendency to a consideration of mental conditions. In the little instruction the student gets, he is apt to be made to understand that it is unscientific to think of mental disorders in any other terms than disorders of the brain itself, or cerebral disorders induced by disease of various internal organs' (Meyer 1908, p. 5). '. . . the attitude of fatalistic indifference of a large majority of physicians is euphemistically and systematically justified with . . . dogmatic excuses for inactivity if not for ignorance' (Meyer 1908, p. 6). ' We must show that some of the difficulties are not insurmountable ...' (Meyer 1908, p. 7, italics his). 'To be helpful to the practitioner we must have a good history with special attention to the early developments, and to the possibilities of early management... psychiatry consists in what we have learned to do with the patient ...' (Meyer 1908, p. 8, italics his). He urged hospital staffs to invite the referring clinician to the admissions conferences of their patients, or to hold various state hospitals, I was astounded by the wealth of specific case material, with detailed case presentations and vignettes, and even partial transcripts of patient interviews. This far exceeded the clinical material presented at the recent meeting of the International Society for the Psychological treatments of Schizophrenia and other psychoses (ISPS) in Stavanger, Norway, or at the American Psychiatric Association's recent meeting in Chicago.

The lead article in the second volume of the Bulletin of the New York State Hospitals, published in May 1909, is by Meyer 's assistant, C. Macfie Campbell, who served as an associate in clinical psychiatry, at the Psychiatric Institute, on Ward's Island, New York, and is entitled 'Psychological mechanisms with special regard to wish fulfillments '. Campbell was also an associate in clinical psychiatry at Ward's Island, in New York City, and had read an earlier version of the paper there, in November 1908, almost a full year before the Clark Lectures (Campbell 1909, p. 700). This is the first explicit grateful reference to Freud in this Bulletin. Campbell begins with two vignettes in which the patients' delusions are clearly wish fulfillments. Campbell, after a section connecting fairy tales and wish fulfillments, states, 'The various steps in the development of the psychosis are not as unintelligible as was usually assumed, but may frequently be seen to proceed in a more or less intelligible sequence from actual difficulties in the patient $s$ internal life. It is often extremely difficult to reconstruct this situation from the facts supplied to us by relatives and elicited on a formal examination of the patient' (Campbell 1909, p. 21). He refers to Jung's case write-ups, emphasizing our need to 'appreciate ... the profound significance of the content of the symptoms' (Campbell 1909, p. 21). '... we are no longer satisfied with a priori statement [sic] that such reactions are meaningless, are due to the mere disordered activity of the nervous structures, and therefore not susceptible of psychological analysis. It is this paralyzing assumption that is apt to make us content with formal clinical differentiations, and leads us to look to the various pathological laboratories for further light on the conditions leading to these disorders. Thanks to the teaching of Meyer we now approach our cases freed from the incubus of this assumption, willing to accept the facts in their entirety' (Campbell 1909, p. 22). Astoundingly, he then says, 'It is a most pernicious error to assume that, because a physician assigns weight to psychological factors in the development of a psychosis, he

meetings at the district societies, usually very far from the hospitals themselves, and to speak not in generalities on theories of illness, but to stay with the individual life stories and the healing power of arriving with the patients at a shared understanding of their histories. He does not mention psychoanalysis specifically.

11. Campbell says, 'We are especially indebted to Professor Freud of Vienna and to his followers for pointing out the clinical importance of this line of study, and in this presentation of his views the examples furnished by Freud himself will be frequently used (Campbell 1909, p. 13). 
therefore rejects observations of disordered metabolism or of histopathological changes. The error rests on a false abstraction of the psychological from the non-psychological; if one has once dissociated them, he can never bring them together again except by most artificial methods. The dissociation should never have taken place' (Campbell 1909, p. 22). 'The presentation of a series of fully analyzed cases of dementia praecox would be a most desirable contribution to the literature ... I apologize for the rather grandiloquent title of this paper; it might better have been entitled "A plea for a more thorough analysis of cases of dementia praecox and allied conditions"' (Campbell 1909, p. 23).

This 1909 paper is so prescient, has such a current voice, that I will include it in my reading lists to the residents I teach. Meyer, in the open discussion of this paper, said, 'We do know that every one of us has poor methods of thinking in one quarter or another; poor methods of adjustment in one way or another, but we do not like to admit it; but that is just what constitutes the "mental disease" of some of our patients' (Campbell 1909, p. 24). That is, as Sullivan would often say, we are all more simply human than otherwise.

In a 1909 issue of the Bulletin, M.J. Karpas, of the Manhattan State Hospital, presented a 'Partial analysis of a case of dementia praecox', the interesting account of a young unhappily married childless woman suddenly psychotic with relevant delusions. She had been sexually abused in childhood by a priest, but repressed this until the onset of her breakdown, when she had fallen in love with a young Jewish man. Karpas concludes, 'What does the record of this case teach us? First, the importance of psychogenic factors in functional psychoses. Second, that psychotic and neurotic symptoms are governed by complexes which originate from definite undercurrents of patients' mental lives. Third, the profound teachings and methods of Freud, Jung and Bleuler should receive our serious attention for we are indebted to them for the true progress of psychopathology' (Karpas 1909, p. 27).

12. Dr William L. Russell, Medical Inspector of the State Commission, after saying he initially had been skeptical, now was enthusiastic, and recommended that people follow up on the work at Bloomingdale by Dr Hoch. 'Practical therapeutic results have been obtained there' (Campbell 1909, p. 25). Dr George H. Kirby, Director of Clinical Psychiatry at the Manhattan State Hospital, also endorsed this contribution 'from the point of view of dynamic psychology'. 'It is a safe and practical plan of work because we are getting at the real difficulties and conflicts which the patient has had to meet and over which he has apparently gone to pieces. To understand the mechanism by which these painful experiences become moving forces in the individual's life and give form and color to the psychosis is a most welcome addition to our knowledge. We cannot deny that psychogenetic factors play an important role in the etiology of mental disorders and as such they deserve our closest attention. The psychoanalysis of a case requires a good deal of time; but one case thoroughly worked out and understood will do much to broaden one's horizon and stimulate interest in the study of symptoms which otherwise would remain as unintelligible and disjointed reactions' (Campbell 1909, pp. 25-26).
The Bulletin's 1910 lead article is again by C. Macfie Campbell, `The form and content of the psychosis; the role of psychoanalysis in psychiatry'. He presents two cases, of a patient who had responded well to psychodynamic treatment of four months' duration, and another who had not. 'Taken on its face value each symptom has little importance; seen as symbols and investigated in their inner meaning these symptoms throw a flood of light on the play of disturbing forces in the patient's life; and only when the psychosis is seen as the resultant of such forces, is it fully understood' (Campbell 1910, p. 19).

In 1910, Adolf Meyer received word that he had been appointed the first head of psychiatry at Johns Hopkins School of Medicine. He left the Psychiatric Institute in New York, and the editorship of the Bulletin passed on to Albert Warren Ferris, who had served as Meyer's assistant editor. The Bulletin lost its psychodynamic portion. In 1913, just one year after the appearance of the German Imago in January 1912, and just a few months after the Zeitschrift was launched, the United States had its first analytic journal, the Psychoanalytic Review. Unfortunately, its lead article was the first of C.G. Jung's Fordham Lectures. The journal's co-editor, Smith Ely Jelliffe, had invited Jung to deliver these talks, unaware that Jung would delineate his differences with Freud. Jelliffe could not realize the profound sequellae. For years, Freud was negative about Jelliffe, even calling him a liar. It was not until 1926 that Jelliffe and Freud corresponded explicitly about Freud's negative impression of Jelliffe. Ernest Jones seems to have stirred the pot again, as he had regarding Sandor Ferenczi (Burnham 1983, pp. 223-224). John C. Burnham's excellent biography of Jelliffe includes Jelliffe's full correspondence with Freud and Jung. Jelliffe and White published eclectically, including works by former members of Freud's circle. As stimulating as those 1908-1910 Bulletin articles were, they are dwarfed by the scope and quality of those in the Psychoanalytic Review, a truly international journal, which drew heavily on hospital-based analytic work with psychotic patients.

Smith Ely Jelliffe (both an MD and PhD) was a rather heroic figure in

13. By August 1910, Henry P. Frost, First Assistant Physician at the Buffalo State Hospital, would begin his article on 'Hysterical psychoses'. 'My object in this paper is not to add another to the long list of discussions on the nature and relationships of hysteria nor to present, except incidentally, any further exposition of the views most widely accepted at the present time, namely, those of Janet and Freud. Recent psychiatric literature is full of valuable papers along this line which are no doubt familiar to all present' (Frost 1910, p. 207). He presents capsule reports on work with 10 of the 25 patients so diagnosed in the preceding six years, that is, since 1904. '... to discuss profitably several questions: (1) whether the cases we meet in our hospital service conform to the description of the "mental accidents" of hysteria as given by Janet; (2) whether these psychoses and the conditions underlying them are explainable on Freud's theory of conversion; (3) whether, and to what extent, a psychoanalysis by the method of Freud is helpful in the treatment' (Frost 1910, p. 208). 
American psychiatry. He wrote prolifically and eloquently about psychoanalysis, reaching a wide audience, both medical and general. His students nicknamed him 'Windy Jelliffe' (Burnham 1983, p. 45). At age 30, having become interested in neurology, Jelliffe worked in the summer of 1897 at the Binghamton State Hospital, where he met his lifelong friend, William Alanson White. Both had grown up in Brooklyn; both were writers. ${ }^{14}$ Jelliffe decided to specialize in psychoanalysis after regularly walking home from work through Central Park with A.A. Brill in 1910.

The initial psychoanalytic fervor in the United States owes much to Jelliffe for his full and lucid reports on European analysts' works, described with infectious enthusiasm. Karl Menninger credits Jelliffe with igniting his analytic interest (Burnham 1983, p. 157). Jelliffe was a synthesizer, striving to keep areas of specialization united or bridged: first, botany with zoology, then neurology with psychiatry, psychiatry with psychoanalysis, and, finally, internal medicine with psychoanalysis. He coined the term 'psychosomatic'. His own genealogy and the impact of emigration fascinated him. He influenced Eugene O'Neill's (1956) creation of Long Day's Journey Into Night. His bibliography stretches to 17 pages of text. During some years, he wrote 16 articles. He corresponded prolifically, and catalogued these letters in systematized notebooks now available at The Library of Congress.

Quoting John Burnham, 'Unlike most analytic therapists, Jelliffe took substantial interest in the use of psychoanalysis in cases of psychosis. Although his statements were very cautious, and he held out little or no hope that psychoanalysis would benefit the patient, he did believe that psychoanalysis might help the physician to understand the case . . . [He wrote,] "I have sat by a mute katatonic [sic] for an hour, attempting a variety of openings with all the zest which in my younger days had been given to a game of chess" ' (Burnham 1983, p. 76 - ref. 79, ch. 2). 'Jelliffe also apparently started

14. 'This summer I am spending my vacation at an Asuylam [sic], more ephoniously termed a "State Hospital", with 1300 patients of all conceivable types. I am thoroughly enjoying it, going on as a member of the staff, temporarily, and getting what I can out of it ...' (Burnham 1983, p. 38). Jelliffe's first wife died in 1916 of a ruptured cerebral aneurysm. In 1925 his younger son, a medical student at Yale and champion swimmer, died in his room of a gunshot wound.

15. Jelliffe was born in October 1866 in New York City. His father, a schoolteacher and principal, established the first systematic kindergarten instruction in Brooklyn. His mother, too, was a teacher. Jelliffe's enthusiasm about teaching and his generosity in sharing his intellectual interests were family features extending over generations. His first career interest was botany; he published an extensive article on the flora of Prospect Park in Brooklyn, NY, and then taught a lively course on the medicinal uses of plants.

After graduating from Columbia University's College of Physicians and Surgeons in 1890, he became an editor and book reviewer for the Medical Record, then married Helena Leeming, also a scientist and author, who anonymously shared editorial burdens with him. Later, Jelliffe became editor of a weekly, Medical News. In 1896, he began contributing to the Journal of Nervous and Mental Disease, and became its editor in 1901, continuing until 1944, a year before he died. For details of Jelliffe and O'Neill, see Silver 2001 an analysis with Paul Federn, the Viennese analyst [also interested in psychosis], who was visiting New York in 1914, but it was cut short by the outbreak of World War I' (Burnham 1983, p. 74 - ref. 72, ch. 2). Jelliffe met often with Freud and with Jung, and tried to keep a positive regard towards both of them even after Freud and Jung split. This cost Jelliffe his credibility with the New York Psychoanalytic Society, a group he founded, but which for a while excluded him as it became stricter, more orthodox and hostile towards lay analysis, which Jelliffe supported. On these frequent trips, he would get new papers by the various founders of psychoanalysis. He and his wife translated these on the trip home, and published them, along with book reviews and summaries of European analytic meetings, in the Review.

William Alanson White (1870-1937) graduated from Cornell University and then worked at the Binghamton State Hospital where he met his lifelong friend and collaborator, Smith Ely Jelliffe, who had begun work at Binghamton in 1896. 'It was Jelliffe who, early in their relationship, introduced White to the importance of psychoanalysis, although Jelliffe was skeptical from the first about the importance of sex in Freudian theory. The first edition of White's Outline of Psychiatry appeared in 1907, at 232 pages. Gradually enlarging and becoming the standard text for psychiatry in its day, it would go through 14 editions, reaching 494 pages. ${ }^{16}$ In March 1909, six months before the Clark Lectures, when Jelliffe was in Austria, he wrote to White: 'The whole Freud business is done to death. The lamp-posts of Vienna will cast forth sexual rays pretty soon ... I suspect William Tell's apple must have been a pair of testicles' (Perry 1982, p. 186, quoting Nolan

16. William A. White to W.A. Robison, 6 March 1917. 'I have your letter of the $24^{\text {th }}$ ult. In re the use of Freudian psychology in this hospital. In response to your request for information I may inform you that for some considerable time past we have been attempting to deal with mental diseases from the psychological viewpoint. If you are acquainted with the history of the care of the so-called insane in this country you will know the remarkable fact that it is only in the past few years that mental diseases have been treated as mental diseases. They have more usually been treated as evidences of physical disorder. We have been approaching the subject from a mental point of view for a long time, and in recent years have gone at it from a psychotherapeutic standpoint. We have followed Professor Freud's work and are using his psychoanalytic methods, without, however, dogmatizing about it or allying ourselves with any special cult.

Our results it is naturally pretty difficult to formulate. A number of cases of very severe types of psychosis have gotten well and gone back to a constructive and productive life, and it would seem that their getting well has been because they were helped along those ways. The critic, of course, would say they would have gotten well anyway, and it is pretty hard to reply to such a statement. What would have happened is always difficult to tell. Aside from the effect on the particular patient, however, the effect upon the general attitude of the hospital towards the patient is exceedingly helpful. Mental diseases have ceased to be stupid affairs to be called by a certain name and then forgotten. They are getting to be filled with interest, and the medical officers themselves profit by the work, I am sure, in very great degree. This profit, of course, also is reflected all along the line and raises the standard of understanding and appreciation of the mental reactions to a higher notch.' (Grob 1985, p. 107) 
D.C. Lewis (1947), 'Smith Ely Jelliffe: the man and scientist', Journal of Nervous and Mental Disease 106: 234-240; see p. 239).

Another key player was Edward Kempf, the first psychoanalyst on the staff of St Elizabeths, arriving there in 1911 from Johns Hopkins by way of Indiana and Illinois. ${ }^{17} \mathrm{He}$ believed himself to be the first analyst in the world to apply analysis to the treatment of psychosis. His book, Psychopathology, published in 1920, was the first American analytic text with application to psychosis. 'The permanent reintegration of schizophrenics into healthyminded and socially understanding egoistic attitudes with practical working efficiency proved that I was able to do what Freud, Brill, and other orthodox psychoanalysts dogmatically held, from their failures, could not be done (Kempf \& Burnham 1974, p. 8). Kempf visited Freud for two days in August,

17. 'In 1911, Edward Kempf had been one of the first psychiatrists in this country to use Freud's dynamic psychiatry in the care of psychotic patients' (Perry 1982, p. 181). In an autobiographical fragment posthumously published in his Selected Papers, Kempf said, My studies in psychology in Indiana University under Professor Ernest K. Lindley, who was a friend of G. Stanley Hall, William James, and Adolf Meyer, decided me to study the medical sciences ... ' (Kempf \& Burnham 1974, p. 6). He read Adolf Meyer on Kraepelin, Ziehen and Wundt, and later discovered Freud's Studies on Hysteria and White's Mental Mechanisms. He worked at the Cleveland State Hospital and then the Indianapolis State Hospital. 'Here in 1912-1913 I applied successfully for the first time in the history of psychiatry the methods used by Freud in analyzing the symptoms of hysteria, to analyzing the symptoms of selected cases of dementia praecox, later called schizophrenia. I was fired from the Indianapolis State Hospital by the elected superintendent, Dr Charles F. Edenharter, a dumb physician but astute politician, for trying to introduce against his approval a medical psychological system of treating the psychoses. Professor Lindley said, upon my reporting my analyses of some cases to him, that my discoveries of the socially sensitized emotional causes of psychoses and neuroses were `as big as the Alps'. He asked me to report them to his friend Professor Adolf Meyer at Johns Hopkins Medical School. As a result I was invited in 1913 to become a member of the medical staff of Phipps Psychiatric Clinic. Here I met, besides Meyer, Macfie Campbell, later Professor of Psychiatry at Harvard Medical School ... I continued here to apply my active method of intimately analyzing by sympathetic questioning the specific experiences that had caused the distressing idea-emotion complexes and impractical social attitudes of schizophrenic patients. Meyer, Campbell and Henderson were unalterably opposed to my insistence that each specific symptom was evidence of a special psychopathological function in the patient that had been caused by special oppressive condemnations by special persons. In othe words the patient had been criticised [sic], shamed, and ridiculed into repressing from consciousness, so as to forget, what had been condemned in himself as shameful, unclean, sinful, and guilty, by someone in his family or other impressive person. My conflict in Phipps with my superiors grew stronger as my reports of successful analyses attracted younger members of the staff to lose interest in neurologizing and give more time to the intimate psychological analyses of their own cases.' Since married resident physicians were barred and since he wanted to marry another Hopkins doctor, Dorothy Clarke, he left Hopkins. The two combined work and love. Their marriage lasted 57 years, ended by his death. Kempf says, 'I decided to accept Dr. W.A. White's offer of the position of Clinical Psychiatrist at Saint Elizabeth's [sic] Hospital in Washington. In Saint Elizabeths I had complete freedom to think out any problems in psychopathology and psychotherapy and select any male and female cases out of over 3,000 for analysis.' (Kempf \& Burnham 1974 pp. 6-7)
1923. '[Freud] believed that schizophrenia had a defective constitutional basis and was incurable by his method of psychoanalysis. My views were largely in agreement with Freud's except that I held, in addition, from analytical experience that an active method of analyzing the schizophrenic attitude was necessary in order to help the patient reintegrate his egoistic powers of selfdetermination against his submissive reactions to the suppressive pressures of certain members of his family. The passive method of analysis as applied by Freud and his school had proven to be inefficient and time wasting. When I was analyzed by Ferenczi in 1926 I found that my views were consistent with those of Ferenczi and Freud but I had a far deeper physiological and evolutionary biological orientation than they had' (Kempf \& Burnham 1974, pp. 8-9). Kempf's summary uncannily presages the work of Sullivan and of Frieda Fromm-Reichmann, even to the political backlash against accusing the parents of contributing to schizophrenia in their offspring. His book, Psychopathology, published in 1920, influenced O'Neill's character representation of the mother, Mary, in his play, Long Day's Journey Into Night. ${ }^{18}$

Harry Stack Sullivan arrived at St Elizabeths late in 1921, almost 30 years old. He first used the term 'interpersonal' in a 1926 lecture on treating schizophrenia (Perry 1982, p. 180). 'Over a period of almost twenty years, White had made the hospital [St Elizabeths] a national institution, famed for its benign care of patients and for its encouragement of staff initiative, particularly in the use of dynamic psychiatry for psychotic patients 'Perry 1982, p. 180). Lucile Dooley, who would later be a charter member of the Washington-Baltimore Psychoanalytic Society where she served as president from 1933-1935, arrived at St Elizabeths in 1916, five years before Harry Stack Sullivan. A lay analyst, with a PhD in psychology from Clark University where she had studied under G. Stanley Hall, she later earned an

18. Nethercot's impressive detective work additionally revealed that when O'Neill said to Malcolm Cowley, in November, 1922, 'There are enough case histories in this book to furnish plots to all the playwrights who ever lived,' he was referring to Edward Kempf's Psychopathology. Kempf wrote this textbook while a staff psychiatrist working under William Alanson White at St Elizabeths Hospital in Washington, DC (Engel 1990). I wonder whether Jelliffe gave O'Neill this book. Kempf had previously trained at the Phipps Clinic of the Johns Hopkins Hospital under Adolf Meyer, its first departmental chairman. Kempf states in the preface that the case material was drawn from experiences with patients in both institutions. This volume represents the first American effort to apply psychoanalytic discoveries systematically to the treatment of the psychoses (Gach 1980, p. 145; Engel 1990)

I especially liked Kempf's case presentation and accompanying photograph of a tightly smiling, simpering young woman wearing a floor-length white dress, with wisps of brown hair springing out of place. The caption reads: 'Regression to infancy, thereby escaping the trials of an unhappy marriage and the responsibilities of raising her family.' O'Neill may have used this image to create the character, 'Mary' who manifests a rather unique retrogressive regression. For me, this documents the shaky structure we inhabit when we attempt to move from discussions of characters in a drama to formulations regarding the actual people whose lives are depicted. 
MD at Johns Hopkins and worked under Edward J. Kempf, studying manicdepressive patients, using analytic methods (Perry 1982, pp. 180-1). Kempf had left St Elizabeths officially the year before Harry Stack Sullivan arrived, but he still consulted there. 'Many of Sullivan's most cogent concepts were derived from Kempf's formulations (Perry 1982, p. 181). Kempf referred to 'Not-I, Not-me, Not-myself', used 'preadolescence' for years 3 to 10, and talked of 'social esteem' the way Sullivan used 'self-esteem'.

Lucile Dooley spoke about St Elizabeths and psychoanalysis. ${ }^{19}$ The male doctors served overseas in World War I. 'The women physicians formed a class which met for 20 minutes each morning for an informal lecture by [Dr Dooley]. Each of the seven physicians undertook study of a patient. Dr White was so encouraged by this continuation of interest that he published the outlines of the lectures in the Psychoanalytic Review, and as soon after the war as possible, about 1920, installed a psychoanalytic staff of five; three physicians and two psychologists with sound analytic training. This was perhaps the first really organized psychoanalytic work in this region. Interns and residents began insisting on some regular instruction, so thereafter, for a decade or more, lectures in psychoanalysis formed an important part of the teaching of St Elizabeths' (Dooley 1943, pp. 2-3).

Dooley continued, 'A second center of psychoanalysis rose at the Sheppard and Enoch Pratt Hospital, Towson, Maryland. Dr Ross Chapman had come to the Government Hospital for the Insane as assistant superintendent in September 1916 and had joined the Washington Psychoanalytic Association.

19. Dooley, L. (October, 1943) 'A brief historical sketch of the psychoanalytic movement in the Washington-Baltimore area', Washington Psychoanalytic Society Archives, undated She began, 'Psychoanalysis was introduced into Washington by Dr William A. White, who, never devoting himself to practice of analysis, nevertheless, by publications, by teaching, and by bringing analysts to the hospital of which he was Superintendent, did more than any other one person to initiate the movement here and to foster its growth. In 1913 Dr White and his friend and associate, Dr Smith Ely Jelliffe, through whom his interest in analysis had been aroused, founded the Psychoanalytic Review, the first American periodical devoted to psychoanalysis. It was published in Washington. In 1914 Dr White appointed to his hospital staff a psychoanalyst, Dr Edward J. Kempf. This was the beginning of an enthusiastic study of analysis by almost the whole staff of the Government Hospital for the Insane (St Elizabeths). While very few of these students became analysts, many of them applied analytic psychology to the observation of their patients. The Psychoanalytic Review published no less than 10 papers on analytic subjects by members of the hospital staff in its first three volumes ... testifying to the amount of interest and activity' (Dooley 1943, p. 1). In 1914 the Washington Psychoanalytic Association was organized, its membership coming largely from this hospital staff ..' (Dooley, p. 1). 'Lay members were admitted' (Dooley, p. 2). 'Dr Adolf Meyer had taken the post of head of the newly organized Phipps Psychiatric Institute in 1913 and at this time was a member of the American Psychoanalytic Association. He also encouraged analytic study and treatment of patients in the Phipps Dispensary, as I personally know from experience ... There were never more than four or five doctors in Baltimore who took up analysis, however, until the work at the Sheppard and Enoch Pratt Hospital began. The main development was in Washington' (Dooley, p. 2).
In 1920 he accepted the post of superintendent of Sheppard and Enoch Pratt. It was in the fall of 1921 that he spoke to me of his desire to have an analyst on his staff. This led to Dr Chapman and Dr Sullivan getting together and to Dr Sullivan's joining the staff of Sheppard early in 1923. This began the practice and teaching of analysis at Sheppard which has continued to flourish, to help train analysts and to be fruitful in this region. The first case seminar of this region, familiarly called, 'The Miracle Club', was carried on there (Dooley 1943, p. 3). ${ }^{20}$-Actual teaching in Washington centered at Chestnut Lodge, which [had] been an active center of psychoanalysis for more than a decade' (p. 11). (Fromm-Reichmann had arrived there in 1935, hired as summer help by the Lodge's owner and medical director, Dexter Bullard, Sr. (Noble \& Burnham 1989))

We generally acknowledge the pre-eminence of Harry Stack Sullivan, Frieda Fromm-Reichmann and Karl Menninger as the progenitors of our national efforts. Each of these giants now has a superb biography providing us with extremely readable accounts of their lives, with ample background on those individuals and schools influencing their thinking. Helen Swick Perry's Psychiatrist of A merica: The Life of Harry Stack Sullivan was runner-up for the Pulitzer Prize in biography in 1982. Lawrence Friedman's book, Menninger: The Family and the Clinic, gives a strong sense of the founding and evolution of a great institution. Gail Hornstein's To Redeem One Person is to Redeem the World: The Life of Frieda Fromm-Reichmann is scheduled for release by The Free Press later this year. I have not received an advance copy, but did hear from Joanne Greenberg, author of I Never Promised Y ou a Rose Garden and board member of the US chapter of ISPS. She wrote to me recently saying, 'Wait until you read Gail Hornstein 's book!! It is just about everything we all wanted to say about what happened and what has been happening in psychiatry recently - it seems to me she got it all right. Like any really good biography, she does the milieu, but also the writing is good, and the conclusions she comes to are what we all would have wanted.

20. The second Washington Psychoanalytic Institute was founded in April 1924. Its fifth year anniversary was featured in the April 1930 issue of the Psychoanalytic Review (the first existed from 1914 to 1918) (Dooley 1943, p. 5). Here, she is quoting from the Review. The third, the Washington-Baltimore Psychoanalytic Association was founded on 31 May 1930. 'Its first preoccupations were with its affiliations with the American and the International Associations."Meanwhile the American Association was being reorganized as a federation of local societies, completed in 1932' (Dooley 1943, p. 8). 'Until 1931 there had been no training institutes in America, though the Berlin, Vienna, Zurich, Budapest and London Institutes had been growing up during the previous fifteen years. New York Institute got under way in 1931, followed soon by Boston and Chicago.' Washington began classes in January 1933 (p. 9). The Institute began in 1939, independently as an activity of the Washington-Baltimore Psychoanalytic Association until 1943, collaborating with the Washington School of Psychiatry, until that summer when the School enlarged its program without consultation with the Institute.

21. I now have commented upon Hornstein's biography (Silver, in press). 
Just as Freud ignited enthusiasm in psychoanalysis among hospital-based American psychiatrists already acquainted with his theories, Fromm-Reichmann, beginning in 1935, found a receptive audience to her message of treatability of psychosis through active psychoanalytic applications. She brought an eclectic orientation combining teachings of the Berlin Psychoanalytic Institute, and of Sandor Ferenczi from Budapest and Georg Groddeck from Baden Baden (Silver 1993). ${ }^{22}$ Fromm-Reichmann, Ferenczi and Groddeck $^{23}$ were a trio creating an inspirational analytic perspective of hopefulness and egalitarianism. Fromm-Reichmann was immediately taken with Sullivan's orientation, so intrinsically aligned with hers. She had brought the European and he the American legacy of knowledge of the usefulness of active applications of psychoanalytic ideas for treating psychosis.

Sullivan's ${ }^{24}$ great success with his unit at the Sheppard and Enoch Pratt

22. Ernst Falzeder, who had attended my study group during his year in Washington as a Woodrow Wilson Scholar, emailed me from Salzburg on 24 April 1997. He shared his excitement on discovering the following letter from Ferenczi to Freud, dated 19 August 1927: Ferenczi was 54 years old (six years before his death), and Fromm-Reichmann was 38. 'I am expecting for next Sunday the announced visit of the Southwest Germans (Landauer, Happel, perhaps Meng, Herr and Frau Dr Fromm-Reichmann). Frau Dr Fromm-Reichmann is coming over to me once a week from Heidelberg. She is an astute, analytically extremely talented person.'

23. Groddeck helped Fromm-Reichmann as she established her sanatorium in Heidelberg, which she opened in 1924. Fromm-Reichmann helped Groddeck, hosting the scientific meetings at his Baden-Baden sanatorium. Groddeck would call on her to comment whenever the topic turned to female sexuality. These remarks formed the basis of Fromm-Reichmann's first presentation in Washington, upon her arrival in 1935 (FrommReichmann 1995). She may have been in the background for all Ferenczi's visits to Groddeck between 1924 and Groddeck's death in 1933.

24. Helen Swick Perry and others have speculated that Harry Stack Sullivan was hospitalized for two years following his expulsion from Cornell, in the academic year 1908-9. He was attending Cornell having scored the highest in Chenango County on the Regents Scholarship exam. He had been caught in a robbery scheme in which students who were bringing the mail from Ithaca to the campus were opening letters and removing enclosed cash. The next two years have remained a mystery. Perry has explored hospital records looking for Sullivan's chart, to no avail, but still there is this lore that he was so gifted with schizophrenic patients because he himself had been one. Some have speculated that A.A. Brill treated him. Perhaps. But then, wouldn't Sullivan have emerged a Freudian, rather than someone who, while naming Freud as his primary inspiration, provocatively referred to him as 'Frond'? More likely, he had worked as an aide at a state hospital or private sanitorium, where an enlightened administrator, in the tradition described by Adolf Meyer (or perhaps even Meyer himself) knew the importance of working with the staff Or perhaps he met with Ross McClure Chapman or even William Alanson White directly after his Cornell crisis. As Perry states, 'From the time White first went to Binghamton, he began to take an interest in crime and mental illness, and this interest continued throughout his professional life ...' (Perry 1982, p. 126). Thus it would be no coincidence that Sullivan grew up in Chenango County, just a few miles from the Binghamton State Hospital where Jelliffe and White met, nor that he came to Washington from Chicago, and worked at St Elizabeths Hospital where White was superintendent. White, summing up his Binghamton experience that went from 1892 to 1903 when he was appointed by
Hospital, where he chose and trained his aides, became his legacy. He, like Jelliffe, was a great synthesizer, organizing two pivotal colloquia, in 1928 and 1929 , bringing together prominent social scientists with psychiatrists. This wide interdisciplinary collaboration would later form the basis of the Washington School of Psychiatry and its one-time New York branch, The William A. White Institute. Never on the Lodge staff, Sullivan held extensive seminars with the staff. ${ }^{25}$ The mutual support of Sullivan and FrommReichmann led to Chestnut Lodge 's prominence and that of the Sullivanian interpersonal school of psychiatry. We can find Ferenczian resonances in Joanne Greenberg's (1964) classic novel of her recovery from schizophrenia, I Never Promised You a Rose Garden. This perspective is now coming into resurgence in two-person, intersubjective analysis.

Fromm-Reichmann and the colleagues she trained at Chestnut Lodge, Otto Will, Harold Searles, Ping Nie Pao and others, made the Lodge the premier sanitorium for analytically oriented treatment. Fromm-Reichmann, Alberta Szalita-Pemow, Sandor Rado, Silvano Arieti and other European immigrants, who fled the Holocaust, stimulated much optimism and scholarly interest in psychodynamic treatment of people suffering from psychosis. Fromm-Reichmann's classical work, Principles of Intensive Psychotherapy, published in 1950, was read by essentially all trainees in the mental health field, even into the early 1980s, and has been continually in print. The central thesis was the importance of personal honesty on the part of the therapist. The clearer he or she is about the moment-to-moment shifts in affect and associations to what is said or done in the hours, the more powerful the therapist becomes. Harold Searles's interviews of patients, observed by psychiatric residents and hospital staff around the country, left a lasting impression and provoked a continuing challenge to their notions of therapeutic zeal. He challenged their misguided attempts to be simply good,

President Theodore Roosevelt to head the Government Hospital for the Insane in Washington, DC (St Elizabeths Hospital), said that patients `are very much more like the rest of us than they are different from us' (in Perry 1982, p. 122 - she does not give the relevant reference, however). Ross McClure Chapman worked at Binghamton from 1908 to 1916, then went to St E's and then headed the Sheppard and Enoch Pratt Hospital in Towson, MD (Perry, p. 121). Perry adds, 'The legend of White as a benevolent physician remains strong to this day in Chenango County; and most people feel that it is logical that Harry Stack Sullivan would name his foundation after White.

25. Harry Stack Sullivan had, in the early 1930s recommended to his friend and almost fiancee Clara Thompson that she go to Budapest, to Sandor Ferenczi, for her psychoanalysis, since he was Sullivan's favorite and actually the only one he had any use for, and then she should come back and analyze Sullivan. She worked with Ferenczi over the course of the next four years, and thus knew Frieda Fromm-Reichmann and Erich Fromm at least from their times at Groddeck's sanitorium in Baden Baden. Sullivan had been impressed by Ferenczi's work and, when Ferenczi was in New York, Sullivan attended his talks, and tried to persuade William A. White to fund a four-month stay in Washington for Ferenczi. White facilitated a much shorter visit, which included five talks on sexuality at the Washington Psychoanalytic Society. 
kind and noble physicians, perceiving that such a false self would leave little with which the patient could identify.

American psychoanalytic metaphoric war intensified during World War II, as orthodoxy gained guild control, while the liberal wing captured the public's attention. The American Psychoanalytic Association, now established as a federation, set standards which almost completely limited nonMDs from careers in psychoanalysis and placed formidable barriers in the career paths of those MDs not limiting their careers to orthodox private practice of psychoanalysis. ${ }^{26}$ But in the 1940s and 1950s, Karen Horney's and Fromm's books were repeatedly on The New York Times bestsellers list, as in the 1960s and 1970s was Joanne Greenberg's I Never Promised You a Rose Garden. Probably dissident status supported group cohesiveness and stimulated erudition. Heated debate forged stronger theories.

Yale University, through Eugene Brody's efforts, became a major source of younger Chestnut Lodge staff members. In the introduction to Psycho therapy with Schizophrenics, which he co-edited with Redlich, Brody wrote, 'The impetus for publication of this volume came from the Conference on Psychotherapy with Schizophrenic Patients held in the Department of Psychiatry of the Yale University School of Medicine in New Haven on 6 December 1950. The idea for such a conference originated when Dr E.B. Brody traveled to a psychiatric center in a neighboring state to hear Dr Frieda Fromm-Reichmann speak on problems involved in the psychotherapy of schizophrenics. He was impressed by the number of physicians, especially psychiatric residents, who had come from many miles to hear the discussion, and felt that there existed a definite need for more intensive contact with current thinking in the field that would be supplied by a conference on the subject. Such a meeting would have the function not only of teaching, but of stimulating research' (Brody \& Redlich 1952, p. 7).

A list of the Berlin Psychoanalytic Institute emigres to the United States includes many of the major targets attacked by the analytic orthodoxy: Karen Horney, Franz Alexander, Sandor Rado, Frieda Fromm-Reichmann and Erich Fromm. Karen Horney had been the only woman among the founders of the Berlin Psychoanalytic Institute. She lost her teaching privileges in the New York Psychoanalytic Society in 1942 in reaction to her ideas on culture and on female psychology. The ferment of alliances that followed led to the founding of many alternative analytic training programs and organizations such as the American Academy of Psychoanalysis. Clara

26. Authors have told me of submitting articles to the American Psychoanalytic Association's journal and being told to resubmit, omitting particular references. Those applying for certification received letters of rejection, 'While you may be very helpful to these admittedly disturbed patients, this is not psychoanalysis as we know it, and we are at a loss as to what to suggest to you', even when the write-ups were of neurotic patients. And
institutes with a history of interest in these non-classical areas received especially taxing institutes with a history of interest in these
Thompson, who trained under Adolf Meyer at Hopkins, and was later an analysand of Sandor Ferenczi, and almost the fiancee of Harry Stack Sullivan, was the Washington Psychoanalytic Society's first president. She went on to head the White Institute in New York. Meanwhile, the Jungians proceeded on their own, analytic work with psychotic patients being included but not predominating.

Today, the United States continues to endure the effects of the insurance industry's creation of managed care firms which have set policies which are extremely constricting of hospital care. While this has affected all branches of medicine, psychiatry has been hardest hit, and its institutions the most devastated. The Sheppard and Enoch Pratt Hospital in Towson, MD, where Sullivan ran his famous pioneering ward in the 1920s, no longer has an independent residency training program. Patients stay usually just a few days, and those on the admissions unit are not assigned an individual psychotherapist. The Yale Psychiatric Institute has recently been sold to the YaleNew Haven Hospital which will bring in its own directors. Chestnut Lodge/CPC filed for Chapter 11 bankruptcy protection on 11 October 2000 and closed in April 2001. Austen Riggs meanwhile seems to be continuing in its grand and stately tradition, but still just with open wards, screening admissions, not taking on acutely suicidal or violent patients.

In all our hospitals, complicated psychopharmacologic regimens are applied for all patients, psychotic or borderline. It is routine for the psychiatrist to address crises with a medication adjustment rather than to enquire of the therapist, if indeed there is one, about the recent events in the patient's life, and the forces at play in the psychotherapy. The 1998 PORT study (The Schizophrenia Patient Outcomes Research Team Treatment Recommendations, headed by Anthony Lehman and Donald Steinwachs), which is quoted in the brochure on schizophrenia produced by the National Alliance for the Mentally Ill (NAMI), states:

Individual and group psychotherapies adhering to a psychodynamic model (defined as therapies that use interpretation of unconscious material and focus on transference and regression) should not be used in the treatment of persons with schizophrenia. Rationale. The scientific data on this issue are quite limited. However, there is no evidence in support of the superiority of psychoanalytic therapy to other forms of therapy, and there is a consensus that psychotherapy that promotes regression and psychotic transference can be harmful to persons with schizophrenia. This risk, combined with the high cost and lack of evidence of any benefit, argues strongly against the use of psychoanalytic therapy, even in combination with effective pharmacotherapy. (Review reference: Scott, J.E. \& Dixon, L.B. 'Psychological interventions for schizophrenia'. Schizophrenia Bulletin 21(4): 621-630, 1995, p. 623, level of evidence: C, recommendation based primarily on expert opinion, with minimal research-based evidence, but significant clinical experience.) (Lehman \& Steinwachs 1998)

This is quoted in the recent report of the Surgeon General, David Satcher $\mathrm{MD}, \mathrm{PhD}$. Those of us working analytically with those with psychosis continue 
as dissidents, outside the accepted norms of our community. Even many of those in leadership at the International Society for the Psychological treatment of Schizophrenia and other psychoses (ISPS) now emphasize cognitivebehavioral approaches and say they consider psychoanalytic approaches 'dangerous'.

I have worked at Chestnut Lodge since 1976, in both the pre- and postmedication eras there. ${ }^{27} \mathrm{I}$ believe that those of my patients who improved in the earlier era made far stronger recoveries. Three of them entered into marriages that still continue. Now, working with medicated patients, I find we never really grapple with core issues.

With the 1955 discovery of chlorpromazine and the later phenothiazines, pharmacology became the new hope in treating schizophrenia. These medicines would fuel enthusiasm for deinstitutionalization, the emptying and closing of the vast warehouses of the chronically ill and psychodynamically ignored. Community psychiatry received national support beginning in the John F. Kennedy years. Psychodynamic hospitals such as Chestnut Lodge, Austen Riggs and Menninger continued long-term intensive treatments. But by the 1980s, insurance companies had formed managed care corporations aiming at cost curtailments. Of all the medical specialties, psychiatry formed its easiest target since we do not use technologically advanced equipment. The hospitals were far easier targets than were individual practitioners.

27. I received weekly supervision from clinicians who had worked with Fromm-Reichmann, and was in twice-weekly small group meetings with them and younger colleagues. mann, and was in twice-weekly small group meetings with them and younger colleagues.
My analyst was Harold Searles. I had the privilege of treating patients who were taken off their meds soon after admission, and who could be in cold wet sheet pack when overwhelmed with anxiety. During those years, I saw profound improvement in the quality of life of the majority of patients receiving intensive psychodynamic therapy, even if they still needed institutional care. Three of my 11 patients from those years gained the confidence to marry, and these marriages have survived. The majority chose and developed careers. Some suffered relapses. But now, I feel I never really meet my patients, who are maintained throughout on complex pharmacological regimens. Our work has an as-if quality. None in recent years has developed sufficient self-confidence to marry and, while some hold jobs, few commit to a career path. I love to quote Joanne Greenberg's account of her first experience in pack: 'I was on Main IV, having a very tough time. A doctor, whom I don't remember - since I subscribed to the theory that if you've seen one person, you've seen them all - said, 'I think you need to be in one of these'. So he put me in one. I think it would be a bad idea for anyone who was claustrophobic to be in a cold pack, but for me it was the first time that I was ever able to look down into my mind, to get clear, to be clear. Once that happened to someone who had never had that, I think he would do anything on earth to get it again. That kind of stillness had a clarity, all of that yelling that went on all of the time inside me, wasn't there and I was at the end of it. You're not going anywhere. You are not going to hurt you or it or anything. That's all; that is it. You can fight and fight and fight. I knew that the ability to stop dead and look inside myself was what well people have. And I knew that that high feeling in the pack was coming from me, not a drug. I learned for the first time that there's a difference between inside and outside and that inside then became available to me. Once I saw that, once I learned that, I would do anything to promote it.' (McAfee 1989, pp. 520-521)
The United States Chapter of the International Society for the Psychological treatment of Schizophrenia and other psychoses is working to bring to general attention the practical importance of talking cures for those with psychosis. Too often we hear of psychiatrists saying to those who meet regularly with these people, 'Why are you talking to him? I'm giving him medications'. Thus, I have reported on work that has been under a variety of sieges since its inception. Just as people with psychosis are by definition outside the social norm, so too are those of us offering them adaptations of the talking cure. The United States continues its pragmatic orientation, but in the area of psychiatry, in the past two decades, there is an ominous pressure to conform to standards, producing a standardization that threatens not only psychoanalysis but its application to those who, I believe, can benefit from it the most, since they have the most to lose. Now, over a century later, pragmatic American psychiatry has returned to a John Gray perspective, seeking the quick fix for the sick brain, now using complex concoctions of the latest psychopharmacologic products, and closing its asylums. The US Chapter of ISPS addressed this issue at our second annual meeting, 7 October 2000, held at the Washington School of Psychiatry. We heard from Anthony Lehman, senior author of the PORT Report, from William Gottdiener, who has conducted a meta-analysis demonstrating the effectiveness of psychodynamic treatment in schizophrenia, and from Wilfried Ver Eecke, a Lacanian philosopher of psychoanalysis, who critiqued the PORT Report's Recommendations 22 and 26. In a continuation of a Meyerian tradition of finding common ground and speaking common sense, we are working to keep insight-oriented therapy among the recommended approaches to treating those suffering from schizophrenia.

\section{Acknowledgement}

I want to thank my friend, John Gach, who owns and operates John Gach Books, an antiquarian psychoanalytic bookstore conducting over $80 \%$ of its worldwide business over the internet at gach.com. Michael Stone dedicated his book, Healing the Mind, to John, and has quipped that he is forever in John's debt; so am I. These antique journals and texts were in heavy use for this paper. I also appreciate John's years of enthusiastic contributions at the Columbia (Maryland) Study Group on the Pioneers in Psychoanalysis in Europe and the US, which meets at my home.

\section{References}

Alexander, F., Eisenstein, S. \& Grotjahn, M. (1966) Psychoanalytic Pioneers: A History of Psychoanalysis as Seen Through the Lives and the Works of its Most Eminent Teachers, Thinkers, and Clinicians. New York: Basic Books.

Brody, E. \& Redlich, F. (eds) (1952) Psychotherapy with Schizophrenics. Monograph Series on Schizophrenia No. 3. (Introduction R. Knight). New York: International Universities Press. Burnham, J. (1983) Jelliffe: American Psychoanalyst and Physician and his Correspondence with Sigmund Freud and C.G. Jung. Chicago: University of Chicago Press. 
Campbell, C.M. (1909) Psychological mechanisms with special regard to wish fulfillments. State of New York, State Hospitals Bulletin, May. Utica, NY: State Hospitals Press, pp. 12-26.

(1910) The form and content of the psychosis: the role of psychoanalysis in psychiatry State ofNew York, State Hospitals Bulletin, May. Utica, NY: State Hospitals Press, pp. 3-21. Coriat, I.H. (1914) Abnormal Psychology. New York: Moffat, Yard \& Co. Second edition, enlarged first edition, 1910.

(1917) The treatment of dementia praecox by psychoanalysis. J. Abnorm. Psychol. 12: 326-330.

Dooley, L. (1943) A brief historical sketch of the psychoanalytic movement in the WashingtonBaltimore area. Washington Psychoanalytic Society A rchives, undated (October).

Edmunds, L. (1988) His master's choice. Johns Hopkins Magazine, pp. 40—49.

Engel, M. (1990) Psychoanalysis and psychosis: the contributions of Edward Kempf. J. Amer A cad. of Psan. 18: 167-184. Also in A.-L. Silver and M. Cantor (eds) Psychoanalysis and Severe Mental Illness. New York: Guilford Press, pp. 167-184.

Falzeder, E. (1997) Personal communication, 24 April.

Farber, L. (1966) Schizophrenia and the mad psychotherapist. In The Ways of the Will: Essays Toward a Psychology and Psychopathology of Will. New York: Basic Books, pp. $184-208$

Friedman, L. (1990) Menninger: The Family and the Clinic. New York: Alfred A. Knopf.

Fromm-Reichmann, F. (1950) Principles of Intensive Psychotherapy. Chicago: University of Chicago Press

(1956) Reminiscences of Europe. In A.-L. Silver (ed.) Psychoanalysis and Psychosis. Madison, CT: International Universities Press, 1989, pp. 469-481.

(1959) Psychoanalysis and Psychotherapy, ed. D.M. Bullard, Sr. Chicago: University of Chicago Press.

(1990) The assets of the mentally handicapped: the interplay of mental illness and creativity, ed. and intro. A.-L. Silver. J Amer. Acad. of Psan. 18: 47-72.

Frost, H. (1910) Hysterical psychoses. State ofNew York, State Hospitals Bulletin, August. Utica, NY: State Hospitals Press, pp. 207-248.

Gach, J. (1980) Culture and complex: on the early history of psychoanalysis in America. In Wallace, E. and Pressley, L. (eds) Essays in the History of Psychiatry: A Tenth Anniversary Supplementary Volume to the Psychiatric Forum. Columbia, SC: R.L. Bryan.

Greenberg, J. (or Hannah Green) (1964) INever Promised Y ou a Rose Garden. New York: Holt, Rinehart \& Winston.

(1967) In praise of my doctor - Frieda Fromm-Reichmann. Text of acceptance speech for the Frieda Fromm-Reichmann award at the American Academy of Psychoanalysis, p. 75. Contemporary Psychoanalysis 4: 73-75.

Grob, G. (1985) The Inner World of A merican Psychiatry, 1890-1940: Selected Correspondence. New Brunswick, NJ: Rutgers University Press.

Guttmann, M.G. (2001) The Enigma of A nna O.: A Biography of Bertha Pappenheim. Wickford, RI: Moyer Bell.

Hale, N. (1971a) James Jackson Putnam and Psychoanalysis: Letters between Putnam and Sigmund Freud, Ernest Jones, William James, Sant/or Ferenczi, and Morton Prince, 1877-1917. Cambridge, MA: Harvard University Press.

(1971b) Freud and the Americans: The Beginnings of Psychoanalysis in the United States, 1876-1917. New York, London: Oxford University Press

(1995) The Rise and Crisis of Psychoanalysis in the United States: Freud and the Americans, 1917-1985. New York, London: Oxford University Press.

Hornstein, G. (2000) To Redeem One Person is to Redeem the World: The Life ofFrieda Fromm Reichmann. New York: The Free Press.

Jung, C.G. (1913) The theory of psychoanalysis. Psychoanalytic Review 1: 1-40, 153-177, 260-284, 415-430, 2: 29-51.

Karpas, M.J. (1909) Partial analysis of a case of dementia praecox. State of New Y ork, State Hospitals Bulletin, September. Utica, NY: State Hospitals Press, pp. 522-528. Kempf, E. (1920) Psychopathology. St Louis, MO: C.V. Mosby Co.
Kempf, D. \& Burnham, J. (eds) (1974) Edward J. Kempf: Selected Papers. Bloomington, IN: Indiana University Press.

Lehman, A. \& Steinwachs, D. (1998) At issue: translating research into practice: the Schizophrenia Patient Outcomes Research Team (PORT) Treatment Recommendations. Schizophrenia Bulletin 24(1): 1-10.

Leys, R. (1981) Meyer's dealings with Jones: a chapter in the history of the American response to psychoanalysis. J. of the History ofthe Behavioral Sciences 17: 445-464.

McAfee, L. (1989) Interview with Joanne Greenberg: with three poems by Joanne Greenberg. In Silver, A.-L. (ed.) Psychoanalysis and Psychosis. Madison, CT: International Universities Press, pp. 513-533.

McGlashan, T. (1984) The Chestnut Lodge follow-up study: I and II. Arch. Gen. Psychiat. 41: 573-601.

(1986a) The Chestnut Lodge follow-up study, III and IV. Arch. Gen. Psychiat. 43: 20-30, 167-176.

(1986b) Predictors of shorter-, medium- and longer-term outcome in schizophrenia. Amer. J. Psychiat. 143: 50—55,

McGlashan, T. \& Keats, C. (1989) Schizophrenia: Treatment Process and Outcome. Washington, DC: American Psychiatric Press.

Meyer, A. (1908) How can our state hospitals promote a practical interest in psychiatry among the practitioners? State of New York, State Hospitals Bulletin 1(1): 5-20. Utica, NY: State Hospitals Press.

(1909) Modern psychiatry: its possibilities and responsibilities. State of New York, State Hospitals Bulletin 2(2): 323-357. Utica, NY: State Hospitals Press.

(1910) The dynamic interpretation of dementia praecox. Amer. J. Psychol. 21: 385, 403

Nethercot, A. (1960) The psychoanalyzing of Eugene O'Neill: part one. Modern Drama 3 . 242-256.

(1961) The psychoanalyzing of Eugene O'Neill: part two Modern Drama 3: 357-372.

(1973) The psychoanalyzing of Eugene O'Neill: P.P.S. Modern Drama 16: 35-48.

Noble, D. \& Burnham, D. (1989) A history of the Washington Psychoanalytic Institute and society. In Silver, A.-L. (ed.) Psychoanalysis and Psychosis. Madison, CT: International Universities Press, pp. 537-573.

O'Neill, E (1956) Long Day's Journey Into Night. New Haven, CT: Yale University Press.

Pao, P.-N. (1979) Schizophrenic Disorders: Theory and Treatment from a Psychodynamic Point of View. New York: International Universities Press.

Perry, H.S. (1982) Psychiatrist of A merica: The Life of Harry Stack Sullivan. Cambridge, MA The Belknap Press of Harvard University Press.

Quinn, S. (1987) A Mind of Her Own: The Life of Karen Horney. New York: Summit Books.

Rosenzweig, S. (1992) Freud, Jung, and Hall the King-maker: The Historic Expedition to America (1909). Seattle: Hogrefe \& Huber Publishers.

Schafer, R. (1970) The psychoanalytic vision of reality. Int. J. Psycho-anal. 51:270-297.

Schulz, C. (1987) Sullivan's influence on Sheppard Pratt. With appendix: the publications of Harry Stack Sullivan (1924-1933). J. Amer. Acad. Psan. 15: 247-259.

Searles, H.F. (1960) The Nonhuman Environment: In Normal Development and in Schizophrenia. New York: International Universities Press.

(1967) The 'dedicated physician': in the field of psychotherapy and psychoanalysis. In Countertransference and Related Subjects: Selected Papers, Ch. 5. New York: International Universities Press, 1979, pp. 71-88.

(1975) Countertransference and theoretical model. In Gunderson, J. and Mosher, P. (eds) Psychotherapy of Schizophrenia. New York: Jason Aronson, pp. 223-228.

Silver, A.-L. (ed.) (1989) Psychoanalysis and Psychosis. Madison, CT: International Universities Press. (1989) Introduction. In Psychoanalysis and Psychosis. Madison, CT: Internationa Universities Press, pp. 1-20

(1993) Countertransference, Ferenczi and Washington, DC. J. Amer. Acad. of Psan. 21 637-654.

(1997) Chestnut Lodge, then and now. Contemporary Psychoanalysis 13(2): 227-249. 
(2001) American psychoanalysts who influenced Eugene O'Neill's Long Day's Journey Into Night. J. Amer. A cad. of Psan. 29: 267-280.

(in press) A personal response to Gail Hornstein's To Redeem One Person is to Redeem the World: The Life of Frieda Fromm-Reichmann. Psychiatry, 2002.

Silver, A-L. \& Feuer, P.C. (1989) Fromm-Reichmann 's contributions at staff conferences. Chapter 1 in A.-L. Silver (ed.) Psychoanalysis and Psychosis. Madison, CT: International Universities Press, pp. 23-45.

Stanton, A.H. \& Schwartz, M.S. (1954) The Mental Hospital. New York: Basic Books.

Stone, M. (1997) Healing the Mind: A History of Psychiatry from Antiquity to the Present. New York: W.W. Norton \& Co.

White, W.A. (1907) Outline of Psychiatry. Nervous and Mental Disease Monograph Series, No. 1. New York and Washington: Nervous and Mental Disease Publishing Co.

White, W.A. (1933) Crimes and Criminals. New York: Farrar and Rinehart.

White, W.A. (1938) A utobiography of a Purpose. New York: Doubleday, Doran \& Co.

\section{ABSTRACT}

This paper documents the informed interest in psychoanalysis in the United States preceding the 1909 Clark Lectures. It traces the evolution of analyticallyoriented treatment of psychosis, work which rarely used classical analytic techniques. Currently such work, while diminished, is supported by the International Society for the Psychological treatments of the Schizophrenias and other psychoses (ISPS). 